\title{
The contentious politics of Tunisia's natural resource management and the prospects of the renewable energy transition
}

Alex Walsh

Coordinator, Algerian Futures Initiative

15 February 2021

\section{Questions}

- What is the relationship between natural resource management and contentious politics, insecurity and instability in Tunisia?

- What are the specific dynamics, risks and opportunities in relation to renewable energy as it relates to conflict and stability?

\section{Contents}

1. Summary

2. The relationship between natural resource management and contentious politics, insecurity and instability

3. Tunisia's renewable energy prospects: dynamics, risks and opportunities

4. References

The K4D helpdesk service provides brief summaries of current research, evidence, and lessons learned. Helpdesk reports are not rigorous or systematic reviews; they are intended to provide an introduction to the most important evidence related to a research question. They draw on a rapid deskbased review of published literature and consultation with subject specialists. 


\section{Summary}

For many decades in Tunisia, there has been a robust link between natural resource management and contentious national and local politics. These disputes manifest in the form of protests, sit-ins, the disruption of production and distribution and legal suits on the one hand, and corporate and government response using coercive and concessionary measures on the other.

Residents of resource-rich areas and their allies protest the inequitable distribution of their local natural wealth and the degradation of their health, land, water, soil and air. They contest a dynamic that tends to bring greater benefit to Tunisia's coastal metropolitan areas. Natural resource exploitation is also a source of livelihoods and the contentious politics around them have, at times, led to somewhat more equitable relationships.

The most important actors in these contentious politics include citizens, activists, local NGOs, local and national government, international commercial interests, international NGOs and multilateral organisations. These politics fit into wider and very longstanding patterns of wealth distribution in Tunisia and were part of the popular alienation that drove the uprising of 2011. In many ways, the dynamic of the contentious politics is fundamentally unchanged since prior to the uprising and protests have taken place within the same month of writing of this paper. Looking onto this scene, commentators use the frame of margins versus centre ('marginalization'), and also apply the lens of labour versus capital. If this latter lens is applied, not only is there continuity from prior to 2011, there is continuity with the colonial era when natural resource extraction was first industrialised and internationalised.

In these ways, the management of Tunisia's natural wealth is a significant part of the country's serious political and economic challenges, making it a major factor in the street politics unfolding at the time of writing.

There is no shortage of case studies illustrating these politics, which are particularly well documented by NGOs and those using the extractivist critique. This critique highlights the role of international capital in the extraction and exploitation of Tunisia's national wealth. The link between natural resource management and conflict is well demonstrated across time and space and across different natural resource types (phosphate, oil and gas, water, soil, and landscapes). The sources are mostly very sympathetic to residents of the resource-rich regions, and largely use narrative approaches to tell the story, rather than quantitative data. What appears to be missing is a detailed account of value chains and where profits accumulate. Without doubt, there are fewer sources looking on from the perspective of international companies.

The development of Renewable Energy (RE) may have some transformative potential for these contentious politics. By 2030 , Tunisia's energy strategy sees $30 \%$ of energy demand to be met with RE. This growth of RE into the national energy mix may offer opportunities for empowering currently marginalized regions through dispersing decision making and offering cheaper, locally produced energy. The development of RE offers a modest amount of jobs, which will ease, to a small extent, the problem of unemployment. RE also allows opportunity for reform of Tunisia's fossil fuel subsidies, which are a costly and regressive.

Each of these prospects promise to offer something towards a more equitable and harmonious future path for Tunisia. However, while RE is developing, it is not yet proven in terms of these results. The RE growth in the energy mix is not on track, job creation depends of a number of variables and when it comes to 'energy democratization', some critics argue that RE development is reproducing existing national power dynamics. There is nonetheless a very strong level of national and international support for Tunisia's RE goals, both in financing and capacity building. The prospects, risks and opportunities of RE are therefore intermingled and remain in the balance. 
Sources in Arabic, English and French are drawn on and are largely gender blind on both subtopics.

\section{The relationship between natural resource management and contentious politics, insecurity and instability}

\section{Tunisia's natural resources}

Natural resources are "stocks of materials that exist in the natural environment that are both scarce and economically useful in production or consumption, either in their raw state or after a minimal amount of processing" (WTO, 2010). This includes familiarly defined resources such as fuels, ores and other minerals, non-ferrous metals, fish, forestry products but should also be broadened to include scenery, biodiversity, water and soil (WTO, 2010).

The literature focuses on Tunisia's phosphates and hydrocarbons and its waters, soils and fisheries. Tunisia's other significant natural resources comprise zinc, lead, barite, iron, salt, and its diverse landscapes. Figure 1 shows the distribution of Tunisia's oil and gas production sites and Figure 2 shows its mineral and agriculture areas, the latter representing soil and water as natural resources.

See : Figure 1. Tunisia's hydrocarbon sites. Source: ETAP, 2020, http://www.etap.com.tn/carte/Carte_hydrocarbures.pdf

Figure 2. Tunisia's mineral and agricultural resources

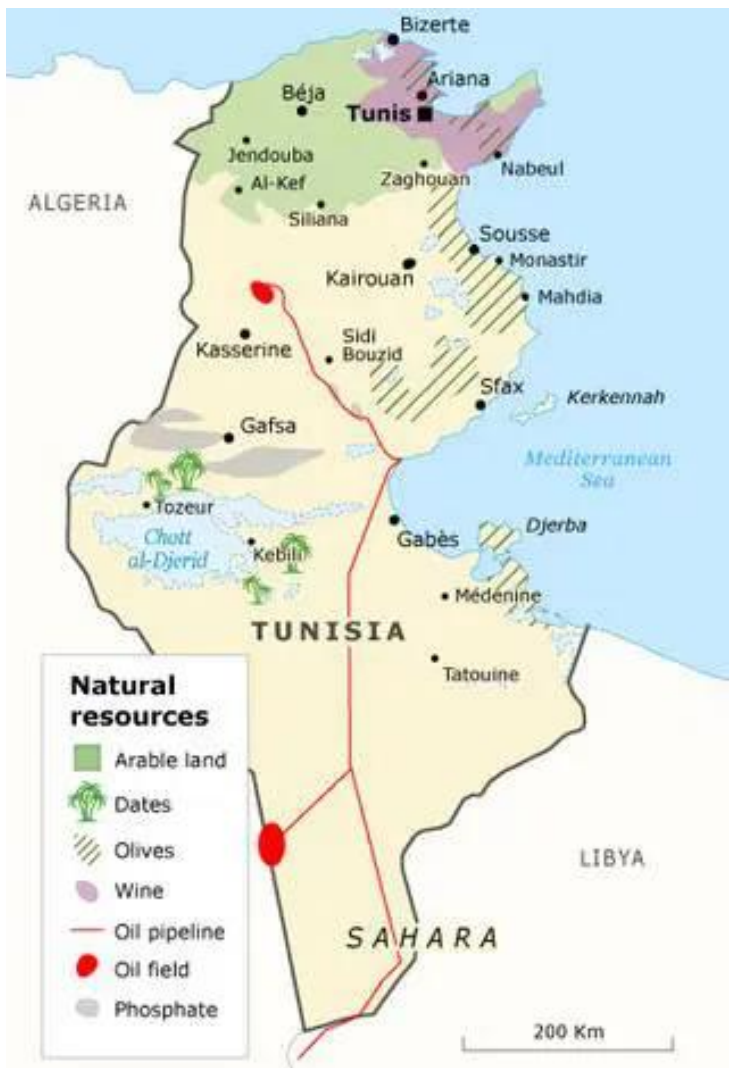

Source: Fanack (2020). Reproduced with permission. 
The extraction, production and transportation of Tunisia's natural resources is a significant part of the economy, and by value added and employment it is agriculture and fisheries that is the most important part of this picture (see figure below). Agriculture and fishing provided $14.7 \%$ of employment in 2016 (CEIC, 2016). Gafsa Phosphate (CPG), the state-owned company employs around 30,000 people, while petroleum products made up $4.1 \%$ of Tunisia's exports. Tourism, which relies on Tunisia's landscape assets among other things, accounts for $8 \%$ of Gross Domestic Product and employs 400,000 people (Arab Weekly, 2020b).

\section{Figure 3. Tunisia's economy in 2019 by value added (millions of Tunisian Dinar)}

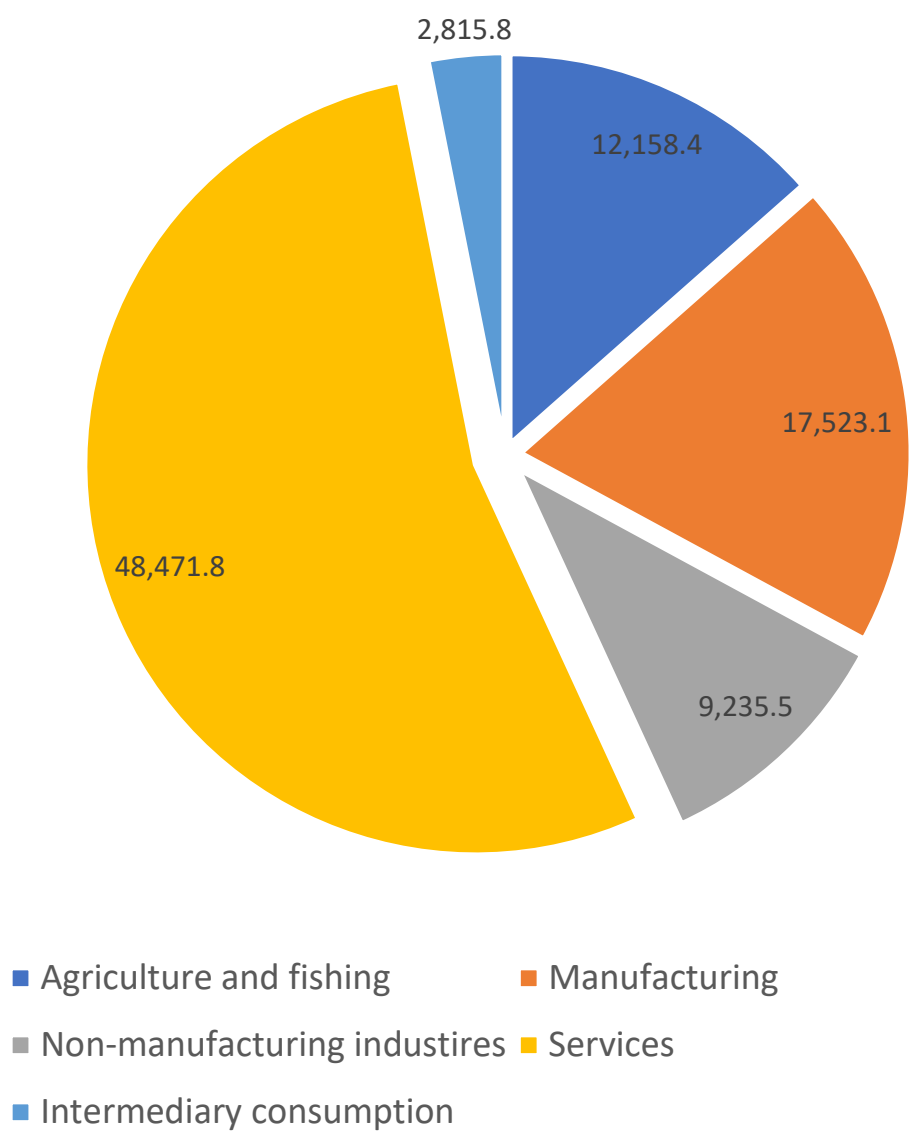

Source: Author's own, data taken from INS (2020a)

\section{Protests and demonstrations}

With regards to Tunisia's management of natural resources, contentious politics form over the distribution of the resulting wealth and the negative side effects. People living in the areas where the natural resources are extracted, processed or transported are aggrieved by the fact few goods accrue to the local level in terms of livelihoods and general development, whereas they pay a heavy price in the pollution of the air, water and soil. These outcomes have negative effects on the levels of human development, health and livelihoods - particularly farming and fishing.

In a 2018 report, the World Bank summarizes the situation (World Bank, 2018): 
The current natural resource management regime limits the ability of communities in resource rich areas to benefit from these resources. Instead, these Tunisians find themselves in resource-rich but employment-poor environments making the reality of their difficult lives more difficult to accept.

The general tendency is for communities in these areas to call for a more equitable distribution of wealth for local development, especially in terms of education, infrastructure and livelihoods (Keskes and Melki, 2018). They also contend for better management of waste products and pollution. Their tools of contention are marches, static demonstrations and sit-ins blocking the sites of production, as well as civil and criminal cases against production companies, and an energetic discourse in graffiti, music, social media and the national press.

Protest discourse can also refer to domestic corruption and exploitation by foreign companies (Yerkes and Muasher, 2017). Civil society organisations (CSOs), such as the Forum Tunisien pour les droits économiques et sociaux (FTDES), are active and allied with these protests, supporting with capacity building, communication, advocacy and bringing civil and criminal suits. Local authorities are also involved along similar lines as CSOs (Mabrouki and Othman, 2020). Majbri et al (2018) have made an account of a number of the community activist campaigns, highlighting where they have had relatively success. There is also attention given to the particular harm accruing to women from phosphate extraction, which reveals that women in the community of Mdhila have a higher than average rate of miscarriage (Kerkes and Melhi, 2018).

Natural resources are extracted, processed and transited by a blend of national and private structures. The Government of Tunisia (GoT) has a somewhat ambiguous position. It tends to maintain current arrangements, responding to protests with a mix of force, promises and minor concessions to local grievances. However, there are judicial routes for redress, there are several government institutions with relevant responsibilities, and the Constitution guarantees many relevant rights, such as the right to a healthy environment. In response to protests, mineral extraction companies also make commitments to corporate social responsibility and local development. In answer to this, communities' complaints of unfulfilled commitments are a common theme in protests (Blaise, 2017; FTDES, 2021). As noted, this pattern appears largely unchanged since the period before the 2011 uprising, although there is now more space for public criticism of public policy and public companies (Amnesty International, 2016).

These contentious politics have led to reductions in production, at the very least in terms of phosphate. Sadiki (2019) estimates this at a cost of US $\$ 180 \mathrm{mn}$, and between 2010 and 2018, phosphate production halved (Laessing, 2018).

The literature bears out these general tendencies in multiple variations covering different natural resources and localities. It is notable that each case implicates the management of a number of different natural resources.

\section{Case studies}

Gafsa is an important region for extraction and processing of phosphate and has been a site of protest for at least the last two decades. Negative side effects for the community include water exploitation for the leaching process and the discharge of untreated wastewater, contaminating water and damaging soil fertility (Hamouchene, 2019a) In 2008, community protests complaining of corrupt hiring elicited a severe security response. Since 2011, several factories and mines in the area have been repeatedly occupied by unemployed youth - for instance in 2017, the Oum 
Laarayes and Redeyef mines production was halted by six-month occupation. At this time, the GoT used a mix of military coercive responses to halt the disruption of production and an offer of jobs to appease protestors. The latest protest occurred in November 2020, when protestors stopped production through a sit in at the phosphate facility (Arab Weekly, 2020).

Another case study around Gafsa concerns the damages done to a home in Redayef in 2020 by explosions detonated for development of the nearby phosphate mine named Shatah Blue. In this case, FTDES has adopted the case against the mining company on the basis of the rights guaranteed by Law no.30 of 2003 (Mabrouki, 2020).

An FTDES publication gives details of another case in region of Gafsa, The municipal council of Mdhila is bringing a civil case against the owners of the a chemical plant in the community, which has been functioning for several decades without proper licences and with serious health effects for community members. FTDES is supporting the municipal council in this suit, brought on the basis of violation of the right to healthy environment (Mabrouki and Othman, 2020). Seeking cooperation and solidarity across the wider Gafsa region, FTDES organised a forum, ${ }^{1}$ to which they invited the governor of Gafsa, CSOs, the UGTT and others (FTDES, 2020a). This forum took aim at the deficiency of mining companies' corporate social responsibility efforts in light of the violations of the right to a healthy environment.

Gabes, a coastal oasis town, is home to a phosphate plant, which pollutes local soils, ground water, and the sea - dumping thousands of tons of untreated phosphogypsum sludge onto shores and into the sea (Rousselin, 2018), leading to degradation of marine habitats (Amnesty International, 2016) and increased levels of respiratory illnesses and bone fragility (Hammouche, 2019a). It has also exhausted ground water, calling into question the nature of Gabes as an 'oasis' (Rousselin, 2018). This has a knock-on effect on livelihoods based on subsistence farming, fishing and fish canning (Hammouche, 2019a). These effects have brought together a mix of farmers, fishermen, canners, phosphate workers, students and other community members in protest since before the 2011 uprising.

Contentious politics in the Kerkeneh Isles focus around hydrocarbons. In 2016, an oil spill led fishermen to protest the endangerment of their livelihoods from repeated spills, as well as coverup operations. In April of that year, protests by unemployed graduates took place in front of the Petrofac gas facility.

Rousselin (2018) makes an account of the case of Jerba, which relates to the management of Tunisia's agricultural natural resources (soil and water). Jerba is an oasis town in the governorate of Kebelil, near to the Chott el Djerid, famous for its dates. In January 2011, residents expelled two corrupt managers with links to the government of Ben Ali. After some tense negotiations, instead of dividing the land and distributing among families as private property, they created a common property regime. This prospered - instead of the US\$60,000 rent they had had to pay to the state under the previous managers, they were able to invest US\$700,000 in local development projects; production of dates doubled and the number of employees increased many times over. The state refused to acknowledge the legitimacy of this structure and the state compelled the residents to

\footnotetext{
1 The forum was called - L'importance du litige environnemental : la Mdhila comme modèle (the importance of environmental litigation: Mdhila as a model).
} 
accept state ownership of the business on the basis that they had seized state land (land that the state had seized at independence, to the chagrin of those claiming historical ownership rights).

Protests in Tataouine Governorate in 2017 offer a slightly different variation. Tataouine is an important transit site for oil and gas but remains economically disadvantaged with an unemployment rate of $36 \%$ at that time rising to $51 \%$ among degree holders. Sit-ins in hydrocarbon facilities calling for $20 \%$ of profits to be invested in Kamour threatened to cut off supply, leading the GoT to agree, via UGTT's mediation, to a settlement involving investment in the area and provision of jobs. However, by 2019 , the social and political justice NGO Nawaat noted that none of these demands had been met (Derbali, 2019). Indeed, just prior to the time of writing, further attempts to block the supply were stopped by the army (Kapitalis, 2021).

These cases illustrate the anger at the disproportionate distribution of the costs and benefits of natural resource extraction on regional areas. The case of Fernana demonstrates this relationship in a more direct way. Residents staged a 'thirst uprising' in 2016 and disrupted the pumping of water from the region to the capital (Pope, 2016) as a protest against water stress and the perceived water greed of the capital. Figure 3 maps various protests according to resource type in Tunisia and in Morocco.

See: Figure 4. Environmental problems and protests in Morocco and Tunisia. Source: (Houdret et al, 2018:2), https://www.die-gdi.de/uploads/media/BP_10.2018.pdf

\section{Wider patterns of maldistribution and contestation}

It is important to note that resource extraction and processing happens in regional contexts (see Figures 1 and 2) rather than in the metropolitan areas. These geographical relations around natural resource production can be framed within wider patterns of regional inequalities in human development in Tunisia, in a phenomenon that is commonly termed "multiple marginalization". Sadiki (2021) looks back into the Bourguiba and Ben Ali eras for the roots of these dynamics:

The country became mired in skewed "metropolis-satellite" interactions: its center would exploit capital and resources from its peripheries, blocking any capacity for economic self-sufficiency or self-renewal. This locked the peripheral regions into a dynamic that exacerbated, rather than eliminated, underdevelopment.

As such, the contentious politics around resource management were a major part of the 2011 uprising. Regional protests over resource management and general economic isolation immediately preceded the 2011 uprising, for instance in Gafsa.

Despite its calls for dignity, democracy and human development, the 2011 uprising has not upset these dynamics. Indeed, the regional-metropolitan inequalities have largely not changed, and in some cases, have grown worse. Unemployment rates range from $9.9 \%$ in the centre and east of the country to $26.2 \%$ in the southwest (ETF, 2021). National poverty rates decreased consistently between 2005 and 2015 from approximately $40 \%$ to $18 \%$ but since then have remained static (WBG, 2020). Indeed, since 2015, certain regions have become poorer, notably the North West, Centre East, Centre West and South West (INS, 2020b). The Institut National de Statistiques' 2020 report opens with the remark that poverty is concentrated in the interior regions in the centre and the north of Tunisia, while greater Tunis, the Northeast and the Centre East experience a low rate of poverty (INS, 2020b). With this context in mind, there is very real continuity in the contentious politics across the 2011 watershed moment. 
This can be seen particularly clearly when considering the Gafsa region. Reviewing the scene just a year after the 2008 'Gafsa Revolt', Gobi (2010) writes:

Throughout the 20th century, this region witnessed a number of work-related conflicts linked to the mine. It was also from Gafsa that, in 1980, an armed operation was launched, aimed at putting an end to Bourguiba's regime. [..] The year 2008 was marked, in Tunisia, by the Revolt of the Gafsa Mining Basin. The social mobilizations which shook this poor area, located close to the Algerian border, represent the most important protest movement seen in Tunisia since the Bread Revolt of January 1984.

The six-month protest movement, which involved a wide variety both peaceful and violent methods, was met with a strong state coercive response, which itself met large cross-sectoral solidarity in turn.

Explaining this continuity, one school of thought takes aim at the type of transitional justice Tunisia underwent. Criticising the Truth and Dignity Commission, it finds that it ignores collective and economic rights and only focused on individual rights (Mullin et al, 2019). This argument contends that Tunisia's transitional justice tended to treat the symptoms of the country's exploitative structures - by for instance prosecuting those responsible for state violence during the 2008 Gafsa Revolt - rather than addressing the wider causes of injustice and the structural violence.

See: Figure 5. Poverty by region in Tunisia. Source: INS (2020b, p.106), http://www.ins.tn/sites/default/files/publication/pdf/Carte\%20de\%20la\%20pauvret\%C3\%A9\%20e n\%20Tunisie_final.pdf

\section{The extractivism thesis}

Allied to this critique of Tunisia's transitional justice in respect of social justice is the 'extractivist' explanation of these contentious politics. Using approaches developed by observers of Latin America, this explanation adds another layer to the concentric circles of exploitation inherent to the "multiple marginalization" diagnosis. It frames Tunisia's natural resource producing regions within global neocolonial structures, whereby its regions are merely places of extraction of primary resources and other land-hungry primary commodities, which can be sacrificed for the benefits of international capital (Hamouchene, 2019a). Concomitantly, with private gain made of public property, little value accrues to Tunisia within this global value chain and even less to the resourcerich regions (Rousselin, 2019).

Within the extractivist thesis, there is a strong criticism of international NGOs and international support along similar lines as the aforementioned criticism of Tunisia's Transitional Justice - that NGOs tend to depoliticise the struggle, avoiding class framings, which distracts from the global capitalist element and renders the struggle one of civil and political rights rather than social justice (Hamouchene, 2019a). Hamouchene is the premier exponent of this framing, and is active in the national Arabic and French, where the idea is becoming more present (Kalboussi, 2020). This is an argument made explicitly in terms of French neo-colonialism by Turkish state media (TRT, 2018). 
Bearing in mind the international involvement in Tunisia's extractive industries, including British firms, this critique is worth considering. However, while it is clear that regions are not benefiting from their natural wealth, what is missing is quantitative account of value chains or an account of the distribution of wealth along national versus international lines. Such an account would help to gauge the depth of the extractivist claim.

\section{Tunisia's renewable energy prospects: dynamics, risks and opportunities}

Tunisia's transition to RE is anticipated in both its technical aspects and the prospects it offers to transform some of Tunisia's most pressing political and socioeconomic problems, including these contentious politics around natural resource management (Döring, 2019). This section briefly summarises the state of the RE transition in Tunisia, looking at the policies and stakeholders. Its main focus is on the risks and opportunities presented by RE development in terms of transforming the contentious politics around natural resource management.

\section{Renewable energy development in Tunisia: a snapshot}

First published in 2009 and revised in 2012, Tunisia's Strategy 30|30, also referred to as the Tunisian Solar Plan (TSP) is the guiding strategy for the country's energy transition. The TSP is somewhat misnamed since solar is neither the only nor the largest source of energy within the plan. It envisages RE to make up $30 \%$ of the energy mix in 2030 comprising (GIZ, 2019):

- 510 Megawatt (MW) Solar Photo Voltaic

- 1755MW Wind

- 450 Thermal Solaire

- $100 \mathrm{MW}$ Biomass

Tunisia's 2030 horizon also sees a $34 \%$ reduction of demand in primary energy demand, a $42 \%$ decrease in Green House Gas (GHG) emissions, and the creation of 23,000 jobs.

According to the US International Trade Association, by end-2019, Tunisia had an installed capacity of $240 \mathrm{MW}$ of wind power, $10 \mathrm{MW}$ of solar, and $62 \mathrm{MW}$ of hydroelectric, representing a combined $6 \%$ of national energy production capacity (ITA, 2020). However, only $3 \%$ of Tunisia's electricity is generated from RE, including hydroelectric, solar, and wind energy. Tunisia has therefore made progress, but is not on track for its 2030 Energy Goals

Another important part of the strategic framework is the Law No.2 of 2015. Law No.2 sets out the framework for large scale renewable energy projects in terms of (a) generation for domestic needs under Power Purchase Agreements, (b) self-generation/consumption and sale of excess, and (c) generation for export - the latter of which is not yet applicable.

\section{Energy imperatives, stakeholders and dynamics}

In terms of policy imperatives, stakeholders and their relationships, the roots of the current dynamic can be traced to the early 2000s, when Tunisia's energy autonomy became a strategic concern with the emergence of a national energy deficit (Rocher and Verdeil, 2019). This was due to a growing domestic demand and shrinking domestic production. Between 1990 and 2014, tons oil equivalent (toe) per citizen per year increased from 5.5 toe to 8.4 toe, while domestic hydrocarbon 
production decreased (Döring and Golli, 2019). Currently, domestic consumption continues to increase by $5 \%$ a year (ITA, 2020). There are hopes that development of the Nawara gas field may decrease the energy deficit.

This situation gave rise to the establishment of Agence nationale pour la matrise de l'énergie (ANME) in 1985, which was mandated with improving energy efficiency and developing RE. As the national state utility, the Société Tunisienne de l'Electricité et de Gaz (STEG) was and still is the most powerful player, operating 92\% of installed production capacity in 2020 (ITA, 2020). The normative basis of STEG's dominant position at the time rested on the conception of energy production and supply as a matter of national independence and pride, a norm that has been more and more disputed since 2011 (Rocher and Verdeil 2013).

Other key state players include the Ministry of Industry and SMEs, formerly the Ministry for Energy and Mines until 2018. The Ministry for Local Affairs and Environment, the Ministry for Development, Investment and International Cooperation are also important. International actors have also played a central role, notably the UN Environment Programme and UNDP, Germany's Gesellschafts fur Internazional Zussamenarbeiten (GIZ), which has supported with capacity building and advice, along with a host of other NGOs. The European Bank for Regional Development has also been very active in supporting the STEG network and supporting ANME in defining the legal framework and offering support to IPPs during tender progress. The EU inter alia has provided a budget support of $€ 50 \mathrm{mn}$ between 2018-2022 to reinforce the Energy Trust Fund, and Agence France de Développement has helped with energy efficiency in social buildings (UNDP, 2018).

The important private stakeholders include users (residential and commercial), and the private companies importing, supplying, installing and maintaining equipment; they also support private users to sign up to government RE instruments. Notably, there is no independent regulatory authority.

\section{Instruments and policy logic}

ANME has rolled out a range of support instruments and salient in the literature are PROSOL (2005) and PROSOL Elec (2009), the former launched in collaboration with STEG, the UN Environment Programme and the Italian Ministry for the Environment, Land and Sea. PROSOL is an instrument that gives credit support to private and commercial users to set up solar thermal water heating, whereby users pay back credit through their electricity bills. PROSOL Elec is an adaptation of the former that support solar photovoltaic electricity production.

Within the broader goal of increasing RE's share of the energy mix, the state instruments also follow other national policy imperatives. PROSOL and PROSOL ELEC, unlike European RE instruments in the main, are based on subsidized credit and loans so that users can afford equipment and set up. This makes them accessible to Tunisian households (Rocher and Verdeil 2019). This design is also driven by the policy goal of creating jobs both directly and indirectly with all sectors that support the set-up of RE technology.

As noted, the 2011 Revolution opened much more space for criticism of STEG's dominant role (Rocher and Verdeil, 2013). STEG is portrayed in a number of sources as an actor defending its dominant position and blocking private initiative, bringing detrimental effects on RE progress (ITA, 2020; Bennis, 2021; Rocher \& Verdeil 2013 and 2019). The politics and relations between the major and minor stakeholders is complex and is reviewed in some detail by Rocher and Verdeil 
(2019), who also point out that STEG sees itself as protecting a national utility from the greed of private investors, as well as considering itself responsible for ensuring the national grid is not overwhelmed by rapid changes leading to overflow. Other observers see blockers in the fact that STEG's employees are unionized and in the numerous changes of energy ministers (Bennis, 2021). There is also criticism of STEG's normative role, made on the basis that energy independence can be managed more effectively by private operators, an argument advanced by senior ANME managers (Rocher and Verdeil, 2013).

\section{Opportunities and Risks}

\section{Progress against goals}

Tunisia's 2030 energy goals promise to decrease its dependence on expensive imported fossil fuels, with attendant decreases in pollution. In 2018, UNDP gave the figure of $4.9 \%$ of Tunisia's electricity generation as based on wind (UNDP, 2018). The IEA gave the following figures for the same year: Hydro $-0.9 \%$ and wind and solar - 1\% (IEA, 2020). Whichever figure is chosen, it is clear that while Tunisia is making progress, but is not on track for its 2030 goals. There was no current reading found on changes in GHG emissions. Despite this, there remain however, ambitions that Tunisia will be able to export RE-generated electricity to Europe (Bennis, 2021).

\section{Job creation}

As noted, job creation is one of the intended outcomes of RE in Tunisia, a country which has been suffering high rates of unemployment for around a decade, especially among youth and young graduates. As noted, this problem also intersects with the region-metropolitan divide, with unemployment higher in the regions.

The most systematic estimation of the number of jobs to be created by RE was made by GIZ in 2016 (Lehr et al, 2016a). This study uses a thorough model to forecast that over 25,000 jobs will be created in the RE and Energy Efficiency Sector by 2030, making a contribution of $1.2 \%$ to GDP. Besides construction, most of these jobs will be created in machines and equipment, and in maintenance, transport and logistics.

In the period 2005-2010, the solar thermal industry created 1,148 jobs and the solar photovoltaic sector created 27 jobs in the same period (Schäfer, 2016). This source estimated in 2016 that 3,390 jobs existed across the RE technology types (solar photovoltaic, thermal photovoltaic, and wind). This does not suggest that jobs in RE are on a linear growth path to the 2030 goals.

Generally, the scenarios looking at job creation by 2030 rely on many variables and a key variable is whether Tunisia relies on imports to develop its overall RE system. A study by the ILO and GIIS sees that the goal of around 30,000 new jobs by 3030 in RE and energy efficiency will be reached if Tunisia's RE economy becomes more integrated and can produce most of the RE system parts. Without such conditions, the estimation falls to 10,000 (Lehr et al, 2018).

Altogether, while these RE jobs will represent an important contribution to the development of the $R E$ and energy efficiency sector, they can only offer opportunities for a small number of the 70,000 Tunisians who graduate each year (Schäfer, 2016), in addition to the stock of existing unemployed 
graduates. Across the whole of the Maghreb (Algeria, Morocco, Tunisia), Schäfer (2016) forecasts that the number of jobs in RE sector will only grow by between $0.2-0.5 \%$.

\section{Decentralization and empowerment: theory and Tunisian experience}

Energy democracy theory examines the opportunities presented by the RE transition for empowering people, including marginalized communities, both in terms of electricity and participation in the economy and politics. Given the patterns of marginalization in Tunisia, this theory is very relevant.

An OSCE review of international RE developments over a decade demonstrated it to be a source of rural economic growth, providing new revenue sources, new job and business opportunities, innovations in products, capacity building and community empowerment through specialization and skills acquirement, local institutions); it can also offer affordable energy whereby the production of local energy is cheaper than central supply (OSCE, 2012a).

Burke and Stephens (2018) theorize that renewable energy opens opportunities for 'democratic energy development', seeing:

centralized renewable energy model as a product of concentrated financial and economic power as well as institutional inertia following a century of centralization [...] "by contrast, a decentralized model of renewable energy development is seen to enable development of renewables at the community level, allowing for new economic and ecological relationships".

A practical example of the dispersion of decision-making comes in the form of the increased number of siting decisions for energy facilities, which can be more numerous than fossil fuel powered plants. In their democratizing potential, RE technologies are not created equal compared to solar technologies, wind and hydroelectric plants are far more capital intensive and resulting of displacements of water, people and agriculture. This is promising for Tunisia, given its emphasis on solar technologies. Examples elsewhere in the MENA region suggest that RE can empower rural women - as in Yemen where women in Abs District of Hajjah Governorate, are running a solar microgrid as a business, in a model that will be reproduced across 100 sites (BBC, 2021).

None of this, however, is a given and RE development can also contribute to marginalization of communities, as documented in the case of one of the world's largest solar park projects, in Charanka, Gujarat, India which dispossessed vulnerable communities through enclosure of common land (Yenneti et al, 2016). RE development can also ignore local economic requirements, be developed without integration into rural supply chains, become dependent on subsidies, suffer from rapid obsolescence, overwhelm local grid capabilities, and compete with other sectors, especially for land.

There is controversy over the decentralizing and democratizing potential of RE to get to grips with the roots of Tunisia's current contentious politics. At one end of the spectrum, Hamouchene (2017) argues that current $\mathrm{RE}$ trajectories merely reproduces the extractionism that he sees as structuring Tunisia's current management of its non-renewable natural resources. Looking at the example of TuNur, he sees a reproduction of neo-colonial relationship under a veneer of RE environmentalism. The solar plant, which is envisaged to supply Europe with power uses the scarce water resources 
in this area for cleaning and cooling of the plant, to generate electricity for Europe, thus increasing the already disproportionate burden on Africa (Hamouchene, 2017).

Despite parliamentary involvement in RE projects, Döring and Golli (2019) argue that the lack of legislative framework organizing participatory processes on national or local level precludes 'procedural justice', or democratic planning and implementation of projects. Placing Tunisia within a broader African context, Müller et al (2020) argue that the country RE's development follows the logic of the market rather than that of 'energy justice' - that it. is not guided primarily by access and affordability, consideration for vulnerable groups nor consultation and participation.

When it comes to women's empowerment, the positive impact on women is yet to be proven in Tunisia. The results of a UNESCWA workshop on the role of RE in empowering rural women in 2019 highlighted that there was at the time at least one women-centred RE projects ongoing in Tunisia (supported by GIZ), but does not show clear results (UNESCWA, 2019). In terms of wider participation of women in the energy sector, ANME and GIZ have highlighted that women make up less than one third of energy sector workers, and less than one in ten of managers (Medener, 2019). This proportion of one in three is almost identical to the number of women in the workforce as a whole, so it does not make the energy sector atypical (UNCTAD, 2019).

There are real life examples of how this lack of energy justice manifests. In 2010, STEG built a wind farm (190 MW) on two sites in the region of Bizerte. Protest of the construction process started in 2011, focusing around lack of development benefit to the localities, lack of job creation. Sabotage of some facilities followed, leading to a pause in construction (Rocher and Verdeil, 2013).

\section{Opportunity to reform of subsidies to fossil fuels}

RE development may provide opportunities to reform fossil fuel subsidies. These subsidies are intertwined with the issues of natural resource management and generally are a factor in the maldistribution of national wealth. Firstly, fossil fuels are expensive, constituting $2.91 \%$ of GDP and around US $\$ 100$ per capita (IMF, 2018) Between 2007-2017 the cost of subsidies was equivalent to $13 \%$ of total state expenditure and 8\% in 2018 (Eibl, 2017; UNESCWA, 2019). Secondly, they are also regressive, generally benefitting the middle-income households more in absolute terms than low income households (Cuesta et al, 2016), and there are other more progressive alternative that are cheaper and more effective (source). Thirdly, they are also part of the structure of Tunisia's dependence on fossil fuels, which has had multiple deleterious fiscal effects, exposing the country to international fuel price increases, limiting its ability to invest in new electricity infrastructure, bringing the subsidy bill to higher than the budget for human development projects, with special suffering from healthcare (Schmidt et al, 2017). Fourthly, they encourage the use of fossil fuels by making them cheaper for consumers, thereby increasing harmful environmental and health effects. They also hinder RE development because they render fossil fuels artificially more competitive than RE.

However, notwithstanding their many strategic disadvantages, reform of these subsidies is difficult and is itself a source of contentious politics. Attempts at reform in 2017 for instance prompted protests because people value them highly and consider them an established part of the social contract (Schmidt et al, 2017). And, even while they are regressive, they remain important for lowincome households whose income they complement most in proportional terms. Indeed, there has 
not been a systematic overall of energy subsidies in the post-2011 period (Eibl, 2017). ${ }^{2}$ In a period of general uncertainty, economic difficulty and popular dissatisfaction such as that which has prevailed since 2011, Tunisian governments have thus been locked into fossil fuel subsidies despite their disadvantages.

RE may provide a way out of this energy policy dilemma and its negative effects. Schmidt et al (2017) argues that there are opportunities in the technical aspects of RE and its distribution that might disrupt Tunisia's lock-in to fossil fuel electricity generation and its subsidization. He predicts that with RE technology becoming cheaper, it will become more competitive against fossil fuel plants (see Figure 5). He argues that they are RE is already more competitive than new build gas power plants.

See: Figure 6. The price competitiveness of RE technologies will increase against fossil fuel based energy generation. Source: Schmidt, 2017, p.103,

https://reader.elsevier.com/reader/sd/pii/S0959378016306057?token=5DCFC0E2FC6FC4137C8 A7C67C118F6D2AEB476E4F64621B62AAA3894D3BE1B918C0D2B78F8F5C073A9675A0BE7 B71EC3\&originRegion=eu-west- 1 \&originCreation=20210420120743

\section{Opportunity and risk to investors}

The competitiveness of RE sources also depends on large part on the interest of investors and the risks and opportunities they face. Tunisia's RE strategy requires approximately $\$ 3.5$ bn of investment by 2030 , and offers various opportunities including equipment sales to STEG for Buildand-Operate and Build-Operate-and-Transfer (ITA, 2020). For instance, in 2018, the Ministry of Mines and Energy published tenders for wind (totalling 500MW) and solar (also totalling 500MW) RE power plants, and by 2019 had awarded all solar projects to private developers (ITA, 2020) There is also the grand plan to connect Tunisia's grid to those of Algeria and Libya towards greater energy integration - as well as the submarine connection to Italy - which will be substantial projects. For now, these projects have been delayed indefinitely (ITA, 2020). A systematic and detailed exploration of risks to investors, which grades the political, financial, physical-chemical, legal, and strategic hazards has been made by Omri et al (2019). To head off political risks, this source recommends participatory approaches, creating employment by establishing an employment commission to look at options, communicate and make information accessible.

\section{References}

Amnesty International (2016) 'Tunisie : le poison de Gabès. Available at: https://www.amnesty.fr/responsabilite-des-entreprises/actualites/tunisie-le-poison-de-gabes

\footnotetext{
${ }^{2}$ In general, economic reform has been minimal "Other than the occasional anti-corruption drive, Tunisia's economic policy has been largely on autopilot, with no government willing to risk sweeping economic reforms." (Grewal, 2021)
} 
Arab Weekly (2020a) 'Protesters halt phosphate production in Tunisia's mining region | AW.' Available at: https://thearabweekly.com/protesters-halt-phosphate-production-tunisias-miningregion

Arab Weekly (2020b) 'Tunisia's tourism sector shows signs of recovery | AW.' Available at: https://thearabweekly.com/tunisias-tourism-sector-shows-signs-recovery

BBC (2021) 'Solar energy empowers young women in Yemen', BBC News. Available at: https://www.bbc.com/news/av/world-middle-east-55894840

Bennis, A. (2021) Power surge: How the European Green Deal can succeed in Morocco and Tunisia - European Council on Foreign Relations. Brussels: European Council for Foreign Relations. Available at: https://ecfr.eu/publication/power-surge-how-the-european-green-dealcan-succeed-in-morocco-and-tunisia/

Blaise, L. (2017) Tunisie : 'À Tataouine, nous sommes tous nés sans travail', Middleeasteye. https://www.middleeasteye.net/fr/reportages/tunisie-tataouine-nous-sommes-tous-nes-sanstravail

Burke, M. J. and Stephens, J. C. (2018) 'Political power and renewable energy futures: A critical review', Energy Research \& Social Science, 35, pp. 78-93. doi: 10.1016/j.erss.2017.10.018.

CEIC (2016) Tunisia | Employment: Industry, Mining, Energy, Construction \& Public Works: \% of Total Employment | Economic Indicators. Available at:

https://www.ceicdata.com/en/tunisia/employment-annual/employment-industry-mining-energyconstruction--public-works--of-total-employment

Chebil, F. (2017) Politique Energetique en Tunisie. Institut Tunisien de la Compétitivité et des Etudes Quantitatives, p. 39. Available at: http://www.itceq.tn/files/developpementdurable/politique-energetique.pdf.

Cuesta, J. A., El-Lahga, A. and Lara Ibarra, G. (2015) The socioeconomic impacts of energy reform in Tunisia : a simulation approach. WPS7312. The World Bank, pp. 1-28. Available at: http://documents.worldbank.org/curated/en/370251468189558300/The-socioeconomic-impactsof-energy-reform-in-Tunisia-a-simulation-approach

Derbali, M. (2019) Tataouine : Sit-in d'El Kamour, le réveil d'un volcan, Nawwat. https://nawaat.org/2019/12/31/tataouine-sit-in-del-kamour-le-reveil-dun-volcan/

Döring, M. (2019) Energy planning towards sustainability. BICC Policy Brief. Bonn International Center for Conversion, p. 9. Available at: https://www.ssoar.info/ssoar/handle/document/62639.

Döring, M. and Golli, R. E. (2019) Country Fact Sheet Tunisia: Energy for the Future. Bonn International Center for Conversion. Available at:

https://menaselect.info/uploads/countries/tunisia/Country\%20Fact\%20Sheet\%20Tunisia_Energy \%20and\%20Development\%20at\%20a\%20Glance\%202018.pdf.

ETAP (2020). Carte Hydrocarbures. Available at:

http://www.etap.com.tn/carte/Carte_hydrocarbures.pdf 
ETF (2019) Tunisia: Education, Training and Employment Developments 2018. European Training Foundation. Available at: https://www.etf.europa.eu/sites/default/files/201903/Tunisia\%202018.pdf

Fanack (2020) Geography of Tunisia, Fanack.com. Available at: https://fanack.com/tunisia/geography/.

Ferdinand Eibl (2017) The political economy of energy subsidies in Egypt and-Tunisia the untold story. The Oxford Institute for Energy Studies: University of Oxford. Available at: https://www.oxfordenergy.org/wpcms/wp-content/uploads/2017/08/The-political-economy-ofenergy-subsidies-in-Egypt-and-Tunisia-the-untold-story.pdf (Accessed: 13 June 2020).

FTDES رسالة للرئاسات الثلاث حول قضية اهالي برج الصالحي FT2021) FTDE. https://ftdes.net/ar/\%d8\%a7\%d9\%84\%d8\%b9\%d8\%b1\%d8\%a8\%d9\%8a\%d8\%a9$\%$ d8\%b1\%d8\%b3\%d8\%a7\%d9\%84\%d8\%a9-

\%d9\%84\%d9\%84\%d8\%b1\%d8\%a6\%d8\%a7\%d8\%b3\%d8\%a7\%d8\%aa-

\%d8\%a7\%d9\%84\%d8\%ab\%d9\%84\%d8\%a7\%d8\%ab-\%d8\%ad\%d9\%88\%d9\%84-

$\% d 9 \% 82 \% d 8 \%$ b6\%d9\%8a/

FTDES. (2020a) ورشة لتقديم نتائج برنامج التبادل الثبابي لمشروع العدالة البيئية Forum Tunisienne des droits économiques et sociaux. https://ftdes.net/ar/atelier-de-restitution-de-levenement-echange-desjeunes-du-projet-justice-environnementale/

GIZ (2019) Projets D’Energie Renouvable: Guide Détaillé. Deutsche Gesellschaft für Internationale Zusammenarbeit. Available at:

http://www.tunisieindustrie.gov.tn/upload/ENR/Guide_detaille_ENR_tunisie_mai2019.pdf.

Gobe, E. The Gafsa Mining Basin between Riots and a Social Movement: meaning and significance of a protest movement in Ben Ali's Tunisia. 2010. halshs-00557826. Available at: https://halshs.archives-

ouvertes.fr/file/index/docid/557826/filename/Tunisia_The_Gafsa_mining_basin_between_Riots_ and_Social_Movement.pdf

Grewal, S. (2021) 'Ten years in, Tunisian democracy remains a work in progress', Brookings, 22 January. Available at: https://www.brookings.edu/blog/order-from-chaos/2021/01/22/ten-years-intunisian-democracy-remains-a-work-in-progress/

Hamouchene, H. (2017) Jemna in Tunisia: an inspiring land struggle in North Africa, openDemocracy, 13 April. Available at: https://www.opendemocracy.net/en/north-africa-westasia/jemna-in-tunisia-inspiring-land-struggle-in-north-africa/

Hamouchene, H. (2017) Another case of energy colonialism: Tunisia's Tunur solar project', openDemocracy, 9 September. Available at: https://www.opendemocracy.net/en/north-africawest-asia/another-case-of-energy-colonialism-tunisia-s-tunur-solar-pro/

Hamouchene, H. (2019) Extractivism and Resistance in North Africa. Amsterdam: Transnational Institute. Available at: https://www.tni.org/files/publication-downloads/web_maghreb_en_21-1119.pdf. 
Houdret, A., Pasqua, I. and Meknassi, S. F. (2018) Access to environmental information: a driver of accountable governance in Morocco and Tunisia? Research Report 10/2018. Briefing Paper. doi: $10.23661 / \mathrm{bp} 10.2018$.

IEA (2020) Tunisia: Renewables Information 2020, International Energy Agency. Available at: https://www.iea.org/countries/tunisia

INS (2020a) Portail de données de la Tunisie, Analyse de Données. Available at: http://dataportal.ins.tn/fr/DataAnalysis?gyAc8uc0bUqgj90vGJL8AA

INS (2020b) Carte de Pauvreté en Tunis. Tunis: Institut national de statistiques. Available at: http://www.ins.tn/sites/default/files/publication/pdf/Carte\%20de\%20la\%20pauvret\%C3\%A9\%20e n\%20Tunisie_final.pdf.

ITA (2020) Tunisia - Power Systems and Renewable Energy, US Department of Commerce: International Trade Association. Available at: http://www.trade.gov/country-commercialguides/tunisia

Kalboussi, M. (2020) En finir avec l'extractivisme ? Nawaat. https://nawaat.org/2020/01/03/enfinir-avec-lextractivisme/

Kapitalis (2021) 'L'armée empêche les membres du mouvement El-Kamour de fermer la vanne de pétrole'. Kapitalis. Available at: http://kapitalis.com/tunisie/2021/02/11/larmee-empeche-lesmembres-du-mouvement-el-kamour-de-fermer-la-vanne-de-petrole/ (Accessed: 13 February 2021).

Keskes, H., et Melki, W. لعنة الفسفاط على نساء ققصة (2018), NRGInstitute. https://resourcegovernance.org/blog/uncovering-impacts-phosphate-mining-tunisian-womenarabic

Laessing, U. (2018) 'Tunisia phosphate exports halted by job protests', Reuters, 16 February. Available at: https://www.reuters.com/article/us-tunisia-protests-idUSKCN1G01XP

Lehr, U. et al. (2018) Green Jobs in Tunisia: Measuring Methods and Model Results. International Labour Organization. Available at:

https://www.greengrowthknowledge.org/sites/default/files/downloads/resource/Green_Jobs_in_T unisia_ILO.pdf

Lehr, U., Mönnig, A., Salem, G. B., et al. (2016) Énergies renouvelables et efficacité énergétique en Tunisie - emploi, qualification et effets économiques - Nouveaux cadres, nouveaux résultats. Deutsche Gesellschaft für Internationale Zusammenarbeit. Available at:

https://energypedia.info/wiki/\%C3\%89nergies_Renouvelables_et_Efficacit\%C3\%A9_\%C3\%89ne rg\%C3\%A9tique_en_Tunisie_\%E2\%80\%93_Emploi,_Qualification_et_Effets_\%C3\%89conomiqu es

Mabrouki, R. النشاط المنجمي بالرديف : تفجير الديناميت يدوّي في قلب المنازل (2020), FTDES. https://ftdes.net/ar/activites-extractives-a-redeyef/

Mabrouki, R., and Ben Othman, R. المعمل الكيميائي بالمظيلة : هل يمحو قرار المحكمة الخرق القانوني ؟ (2020), FTDES. https://ftdes.net/ar/le-groupe-chimique-a-mdhilla-la-decision-de-justice-effacera-t-elle-laviolation-de-la-loi/ 
Majbri, M., Gaaloul, M., and Ben Othman, R. التقرير السداسي لأنشطة قسم العدالة البيئية (2018), FTDES. https://ftdes.net/rapports/rapport.semest.env.pdf

Meddeb, H. (2020) Tunisia's Geography of Anger: Regional Inequalities and the Rise of Populism, Carnegie Middle East Center. Available at: https://carnegie-

mec.org/2020/02/19/tunisia-s-geography-of-anger-regional-inequalities-and-rise-of-populismpub-81086

Medener (2019) 'ANME highlights small percentage of women in Tunisia's energy management sector', Medener, 24 May. Available at: https://www.medener.org/en/anme-highlights-smallpercentage-of-women-in-tunisias-energy-management-sector/

Müller, F. et al. (2020) 'Is green a Pan-African colour? Mapping African renewable energy policies and transitions in 34 countries', Energy Research \& Social Science, 68, p. 101551. doi: 10.1016/j.erss.2020.101551.

Mullin, C., Trigui, N. and Shahshahani, A. (2019) 'Decolonizing Justice in Tunisia', Monthly Review, pp. 22-39. doi: 10.14452/MR-071-01-2019-05_3.

OECD (2012) Linking Renewable Energy to Rural Development: Executive Summary. Berlin: OECD. Available at:

https://www.oecd.org/berlin/Linking\%20Renewable\%20Energy\%20to\%20Rural\%20Development -es.pdf

OECD (2012b) Promoting Graduate Entrepreneurshipin Tunisian Universities. OECD. Available at: http://www.oecd.org/industry/entrepreneurshiptunisia.htm.

Omri, E., Chtourou, N. and Bazin, D. (2019) 'Risk management and policy implications for concentrating solar power technology investments in Tunisia', Journal of Environmental Management, 237, pp. 504-518. doi: 10.1016/j.jenvman.2019.02.049.

Pope, C. (2016) 'Tunisia's Thirst uprising: A Nation on the Edge', Circle of Blue, 27 October. Available at: https://www.circleofblue.org/2016/africa/a-nation-on-the-edge/

Rocher, L. and Verdeil, É. (2013) 'Energy Transition and Revolution in Tunisia: Politics and Spatiality', The Arab World Geographer, 16(3). Available at: https://hal.archives-ouvertes.fr/hal01078983/document.

Rocher, L. and Verdeil, E. (2019) 'Dynamics, tensions, resistance in solar energy development in Tunisia', Energy Research \& Social Science, 54, pp. 236-244. doi: 10.1016/j.erss.2019.04.010.

Rousselin, M. (2018) 'A study in dispossession: the political ecology of phosphate in Tunisia', Journal of Political Ecology, 25(1), pp. 20-39. doi: 10.2458/v25i1.22006.

Sadiki, L. (2019) 'Regional development in Tunisia: The consequences of multiple marginalization', Brookings, 14 January. Available at:

https://www.brookings.edu/research/regional-development-in-tunisia-the-consequences-ofmultiple-marginalization/

Schäfer, I. (2016) The Renewable Energy Sector and Youth Employment in Algeria, Libya, Morocco and Tunisia. African Development Bank. Available at: 
https://www.afdb.org/fileadmin/uploads/afdb/Documents/Publications/The_Renewable_Energy_S ector_and_Youth_Employment_in_Algeria_Libya_Morocco_and_Tunisia.pdf (Accessed: 24 January 2021).

Schmidt, T. S., Matsuo, T. and Michaelowa, A. (2017) 'Renewable energy policy as an enabler of fossil fuel subsidy reform? Applying a socio-technical perspective to the cases of South Africa and Tunisia', Global Environmental Change, 45, pp. 99-110. doi:

10.1016/j.gloenvcha.2017.05.004.

TRT World (2018) Does Tunisia have sovereignty over its natural resources? Available at: https://www.youtube.com/watch?v=Ed0qiOHt79Q

UNCTAD (no date) UNCTADstat - General Profile: Tunisia, UNCTADstat. Available at: http://unctadstat.unctad.org/countryprofile/generalprofile/en-gb/788/index.html

UNDP (2018) Independent Country Programme Evaluation: Tunisia. Available at:

https://erc.undp.org/evaluation/evaluations/detail/9405\#

UNESCWA (2019) Report: National Workshop on "Women Empowerment and Entrepreneurial Development in the Rural Context: The Role of Renewable Energy". Tunis. Available at:

https://www.unescwa.org/sites/www.unescwa.org/files/events/files/report_of_the_national_works hop_on_women_empowerment_in_tunisia_.pdf

World Bank (2018) From Disfavored to Unique: Tunisia's Territorial Variety as an Asset Policy Note on How Tunisia Can Leverage its Regions in a Differentiated Mannerfor Shared Prosperity. Available at: http://documents1.worldbank.org/curated/en/607731539108563827/pdf/FinalRoadmap-Policy-Note.pdf

World Bank (2020) Tunisie.

http://pubdocs.worldbank.org/en/530161587663269627/pdf/2020002219FREfre005-Tunisia.pdf

WTO (2010) World Trade Report 2010: B. Natural resources: definitions, trade patterns and globalization. Geneva: World Trade Organization. Available at:

https://www.wto.org/English/res_e/booksp_e/anrep_e/wtr10-2b_e.pdf (Accessed: 13 February 2021).

Yenneti, K., Day, R. and Golubchikov, O. (2016) 'Spatial justice and the land politics of renewables: Dispossessing vulnerable communities through solar energy mega-projects', Geoforum, 76, pp. 90-99. doi: 10.1016/j.geoforum.2016.09.004.

Yerkes, S. and Muasher, M. (2017) Tunisia's Corruption Contagion: A Transition at Risk. Carnegie Endowment for International Peace. Available at:

https://carnegieendowment.org/2017/10/25/tunisia-s-corruption-contagion-transition-at-risk-pub73522 


\section{Acknowledgements}

We thank the following experts who voluntarily provided suggestions for relevant literature or other advice to the author to support the preparation of this report. The content of the report does not necessarily reflect the opinions of any of the experts consulted.

- Amine Bennis, EBRD

\section{Suggested citation}

Walsh, A. (2021). The contentious politics of Tunisia's natural resource management and the prospects of the Renewable Energy transition. K4D Helpdesk Report. Brighton, UK: Institute of Development Studies. DOI: 10.19088/K4D.2021.048

\section{About this report}

This report is based on nine days of desk-based research. The K4D research helpdesk provides rapid syntheses of a selection of recent relevant literature and international expert thinking in response to specific questions relating to international development. For any enquiries, contact helpdesk@k4d.info.

$K 4 D$ services are provided by a consortium of leading organisations working in international development, led by the Institute of Development Studies (IDS), with Education Development Trust, Itad, University of Leeds Nuffield Centre for International Health and Development, Liverpool School of Tropical Medicine (LSTM), University of Birmingham International Development Department (IDD) and the University of Manchester Humanitarian and Conflict Response Institute (HCRI).

This report was prepared for the UK Government's Foreign, Commonwealth and Development Office (FCDO) and its partners in support of pro-poor programmes. Except where otherwise stated, it is licensed for non-commercial purposes under the terms of the Open Government Licence v3.0. K4D cannot be held responsible for errors, omissions or any consequences arising from the use of information contained in this report. Any views and opinions expressed do not necessarily reflect those of $F C D O, K 4 D$ or any other contributing organisation.

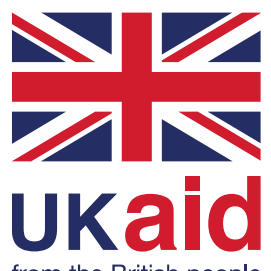

(c) Crown copyright 2021. 